\title{
Assessment of Patronage of Tourist Sites in Badagry Local Government Area of Lagos State, Nigeria
}

\author{
Olugbemi, MoyosoreTitilope ${ }^{1} \quad$ Awotide, Diran Olawale ${ }^{2} \quad$ Akinreti, Naimot Olayinka $^{1}$ \\ Ogungbayi, Gafar Bolaji ${ }^{1} \quad$ Solana, Olorunfunmi, Isimioluwa ${ }^{1} \quad$ Bashorun, Oluwafeyikemi Edith $^{1}$ \\ Akerele, Ezekiel Olaoluwa² \\ 1.Department of Home science and Hospitality Management, \\ Faculty of Agricultural Management and Rural Development \\ College of Agricultural Sciences, Olabisi Onabanjo University, Ayetoro Campus, Ayetoro \\ Ogun state, Nigeria \\ 2.Department of Agricultural Economics and Farm Management \\ Faculty of Agricultural Management and Rural Development \\ College of Agricultural Sciences, Olabisi Onabanjo University, Ayetoro Campus, Ayetoro \\ Ogun state, Nigeria
}

\begin{abstract}
Poor patronage has been a subject of concern in hospitality industry and tourist attraction centres. This has impacted negatively on investment in the sector and overall economic development. The study therefore assessed patronage of tourist centres in Badagry Local Government area (LGA) of Lagos State. Nigeria. The study was based on primary data obtained in a cross-sectional survey of 240 respondents using multi-stage sampling technique in selected tourist centres in the LGA. The data collected were analyzed using descriptive and inferential statistics. Results revealed that majority of the respondents were between 26-30 years of age with an average of 36.2 years. Majority (62.1\%) of the respondents were females, 71.1 percent were single and 41.7 percent had tertiary education. Furthermore, majority $(60.8 \%)$ of the respondents had between 4-6 individuals as household members. The most visited tourist centre recreation purpose $(62.1 \%)$, education purpose $(87.1 \%)$, research purpose $(84.2 \%)$, information purpose $(72.1 \%)$ and sightseeing which accounted for $57.9 \%$. Furthermore, inadequate funding of tourist by the government $(95.8 \%)$, under developed tourism infrastructure $(96.3 \%)$, low patronage $(98.8 \%)$, limited understanding of tourism $(95.0 \%)$ and bad road to tourism destination $(98.3 \%)$ accounted for poor patronage. The study concluded that age, sex, marital status, education, major occupation, working experience and household size of the respondents were associated with their level of satisfaction in the study area. The study therefore recommended that tourism development should not be left alone for the state government, the Local government should make effort to support the state government to create enabling environment to the tourist centres.
\end{abstract}

Keywords: tourists, tourist centres, patronage, level of satisfaction, Badagry

DOI: $10.7176 / \mathrm{JTHS} / 50-05$

Publication date:September $30^{\text {th }} 2020$

\section{INTRODUCTION}

Tourism is identified as an effective way to revitalise the economy of any destination (Long, 2012) and widely acknowledged as one of the fastest growing industry globally (Raymond, 2001; Newsome et al., 2002; Basu, 2003, Jennie, 2012). The continuous and rapid growth of tourism has facilitated increased global disposable income, demand for leisure, and this combine with the global economic restructures in response to globalization that ensured competition in global tourism industry and drastic reductions in travel costs. Thus, tourism has been known as the suitable way for economy growth and development, employment, earnings, foreign exchange for many countries (Khaksari, Lee and Lee, 2014) and considered by developing countries as a main source of development and growth for local economies (Hodur et al, 2005; Haller, 2012).

Nigeria's tourism landscape is extremely rich and beautiful for global tourist attraction; the weather, climate, vegetation, quality airspace, sunshine, beautiful scenery, the rock, falls, captivating beaches, historical relics, rich cultural diversity, friendly peoples and wildlife are Nigeria's tourism assets source. This makes Nigeria a leading tourism paradise in Africa (WTO, 2016). According to the World Trade Organization (WTO, 2016) noted that tourist arrivals reached 1.23 billion, up strongly from 674 million in 2000 . Earnings reached a record US\$ 1.22 trillion, increasing impressively from US\$ 495 billion in 2020. It was further forecasted that international tourist arrivals to African will be to the tune of 77.3 million visitors in 2020. In Nigeria, the downstream economic impacts from the exports revenues of international tourists' spending are estimated to generate additional annual gross revenue of $\$ 224 \mathrm{~m}(\mathrm{~N} 29 \mathrm{~b})$. Furthermore, the market share of emerging economies was not left out in this boom, increasing from $30 \%$ in 1980 to $47 \%$ in 2015 , and is expected to reach $57 \%$ by 2030 , equivalent to over 1 billion international tourist arrivals (UN,WTO’s Long Term Forecast Tourism Towards 2030).

Currently, tourism is no longer leisure but an activity that has captured the attention of economists as a major 
source of foreign exchange for developing and developed countries, compelling aspiring nations to develop both tourist sites, standardize operations and improve infrastructures such as electricity, airports, rail, roads, seaport, that support tourism (Ahmad, 2012; Bogoro et al., 2013; Kumar, 2013; and Mosoma, 2014). Unlike oil that is nonrenewable, and which at best employs less than $2 \%$ of the population, tourism on the other hand, is an all-inclusive, sustainable, labour-intensive industry, engaging both skill and unskilled labour. It has the potential to create more jobs per unit of investment than the oil industry.

Environmentally, tourism, when properly developed and managed, can serve as a mechanism for protecting the ecosystem: the natural environments, preserving historical, archaeological and religious monuments and stimulating the practice of local cultures, folklore, traditions, arts and crafts, and cuisine(Chidozieand Obudo, 2014). Economically, tourism brings many benefits to federal, state and local authorities as well as the private sector through the generation of revenue, foreign exchange, and financial returns on investment, taxation on tourists and tourist products, and linkages to other local industries such as agriculture (Khosraviet al., 2014). The employment reach of tourism is not limited to urban areas but also rural communities that often host tourist sites and monuments. It is based on this that the study assessed patronage of tourist centres in Badagry Local Government area of Lagos State. Nigeria.

\section{METHODOLOGY}

\section{Study Area}

The study was conducted in Badagry, Lagos State, Nigeria. Badagry (traditionally Gbagle) is a coastal town and local government area (LGA) in Lagos State, Nigeria. It is between the city of Lagos and the border with Republic of Benin at Seme. As of the preliminary 2006 census results, the municipality had a population of 241,093. Badagry, a coastal community in Lagos State, prides itself as cradle of civilization in Nigeria. Believed to have been founded in 1425 A.D, the town derived its name from the fusion of the name of its founder, a famous farmer known as Agbedeh and the word "Greme", which means farm in Ogu (Egun) language.

The first educational system in Nigeria as a British colony started in Badagry where the first primary school was established by the Wesleyan Mission (Methodist Church) in 1843 and named Nursery of Infant Church which later became St. Thomas' Anglican Nursery and Primary School, founded by Rev. Golmer of the Church Missionary Society (CMS) in 1845 and operated inside the first storey building in Badagry. In 1863, Badagry was annexed by the United Kingdom and incorporated into the Lagos Colony. In 1901 it became a part of Nigeria. Badagry is naturally endowed with monumental tourist attractions which form part of the Ogu's cultural heritage located on the Guinea coast with its beautiful coconut-fringed sandy beaches dotted with historical sites and relics. The population of the study included all tourism sites, all workers and tourists in Badagry Local Government Area of Lagos State. There are 15 tourist sites which were selected for the survey.

\section{Sampling Technique and Sample Size}

A two-stage sampling technique was used to select respondents for the study. In stage one, $50 \%$ of the 15 tourist sites were selected. In the second stage, 30 respondents (30 tourists) were selected from each of the tourist sites selected. In all, a total of 240 respondents were selected for the study. In addition, the manager and one assistant were interviewed in each of the tourist sites.

\section{Method Data Collection and Data Analysis}

Primary data used for the study were collected through the use of structured questionnaires administered on the tourists. The dependent variable was patronage of tourist sites in the study area. The independent variables included socio-economic characteristics, the various tourist sites and their location in the study area. Other relevant information collected were level of patronage of tourist sites in the study area, tourists' reasons for visiting the tourist sites, level of patronage of tourist site, level of tourist satisfaction and challenges facing tourists in the study area. The data collected were analyzed using descriptive and inferential statistics.

\section{RESULTS AND DISCUSSION}

The sex of the respondents was necessitated for possible inference deduction and generalization on how it relates to tourist centre patronage. As evident in Table 1, majority (62.1\%) of the respondents were females. Marital status is expected to influence respondents' level of responsibilities which could have positive or negative influence on their tourist centre patronage. The results showed that majority $(71.7 \%)$ of the respondents were single. Education background is a vital point of note in enlightenment and tendency towards innovation. The relationship between education and tourist centre patronage formed the basis for examining the educational level of the respondents. the study revealed that the majority $(41.7 \%)$ of the respondents had tertiary education, about $38.3 \%$ of the respondents possessed secondary level formal education while $20.0 \%$ had primary school education, implying that level of formal education may enhance tourist centre patronage by the respondents in the study area. That is, educated people may be more favourably disposed to frequent patronage of tourist centres than those with 
no formal education.

Household size may also have implication on the patronage level of the tourist centres by the respondents. The results presented in Table 1, reveal that the majority (60.8\%) participating respondents had between 4-6 individuals as household members. This medium household size may encourage the respondents to patronize the sites as the cost may not eat deep into the monthly or annually income. The main occupation of the respondents could have effect on regularity of their income. A participant that has regular income source (e.g. salary) may have high susceptibility to tourist centres patronage. An assessment the respondents' main occupation revealed that the respondents engaged in varieties of occupation mainly. However, substantial percentages of the participants $(58.8 \%)$ were students. Religion is said to be the opium of the society precisely in Nigeria and particularly in the study area. Religion often a time determines what people eat, the type of clothes they wear and perhaps the kind of social and economic association they engage in. The practitioners of two major religions in the study area (Islam and Christianity) were represented Muslims respondents being higher than Christians.

Table 1: Socio-Economic Characteristics of the respondents

\begin{tabular}{|c|c|c|}
\hline Age Group & Frequency & Percentage \\
\hline Below 20 years & 16 & 6.7 \\
\hline $20-25$ years & 44 & 18.3 \\
\hline $26-30$ years & 95 & 39.6 \\
\hline $31-35$ years & 43 & 17.9 \\
\hline Above 35 years & 42 & 17.5 \\
\hline \multicolumn{3}{|l|}{ Sex } \\
\hline Male & 91 & 37.9 \\
\hline Female & 149 & 62.1 \\
\hline \multicolumn{3}{|l|}{ Marital status } \\
\hline Single & 172 & 71.7 \\
\hline Married & 67 & 27.9 \\
\hline Divorced & 1 & .4 \\
\hline \multicolumn{3}{|l|}{ Level of education } \\
\hline Primary education & 48 & 20.0 \\
\hline Secondary education & 92 & 38.3 \\
\hline Tertiary education & 100 & 41.7 \\
\hline \multicolumn{3}{|l|}{ Length of day of visit } \\
\hline A day & 238 & 99.2 \\
\hline Two days & 2 & .8 \\
\hline \multicolumn{3}{|l|}{ Household size } \\
\hline $1-3$ & 61 & 25.4 \\
\hline $4-6$ & 146 & 60.8 \\
\hline $7-9$ & 31 & 12.9 \\
\hline $10-12$ & 2 & .8 \\
\hline \multicolumn{3}{|l|}{ Major occupation } \\
\hline Farming & 25 & 10.4 \\
\hline Trading & 43 & 17.9 \\
\hline Civil servant & 29 & 12.1 \\
\hline Artisan & 2 & 0.8 \\
\hline Student & 141 & 58.8 \\
\hline \multicolumn{3}{|c|}{ Years of working experience } \\
\hline None & 141 & 58.7 \\
\hline Below 5 years & 33 & 13.8 \\
\hline $5-10$ years & 60 & 25.0 \\
\hline $11-15$ years & 4 & 1.7 \\
\hline $16-20$ years & 1 & 0.4 \\
\hline Above 20 years & 1 & 0.4 \\
\hline \multicolumn{3}{|l|}{ Religion } \\
\hline Christianity & 98 & 40.8 \\
\hline Islam & 142 & 59.2 \\
\hline \multicolumn{3}{|c|}{ Membership of social group } \\
\hline Yes & 122 & 50.8 \\
\hline No & 118 & 49.2 \\
\hline Total & 240 & 100.0 \\
\hline
\end{tabular}

Source: Field survey, 2018. 


\section{Tourist centers visitation and the location}

The visited tourist sites were the slave relics of Mobee Palace (81.7\%), Q-brat Zoo (82.1\%), Nigeria French language village (93.3\%), Sultan beach (79.6\%), Whispering palm (97.1\%) and Badagry heritage museum (50.4\%) as presented in Table 2.

Table 2: Various Tourist Centers and Location in the Study Area

\begin{tabular}{lccccl}
\hline Tourist centre & Visit & \multicolumn{3}{c}{ Location } \\
\cline { 2 - 5 } & No & \multicolumn{3}{c}{ Yes } & \\
& Freq & \% & Freq & \% & \\
The first storey building in Nigeria & 124 & 51.7 & 116 & 48.3 & Marina Badagry \\
The slave relics of mobee Palace & 44 & 18.3 & 196 & 81.7 & Marina Badagry \\
Q-brats Zoo & 43 & 17.9 & 197 & 82.1 & Araromi- Oko Afo Badagry \\
Nigeria French language village & 16 & 6.7 & 224 & 93.3 & Ajara Badagry \\
Point of no return & 130 & 54.2 & 110 & 45.8 & Gberefu Island Badagry \\
Sultan Beach & 49 & 20.4 & 191 & 79.6 & Fanuvi; \\
Whispering palms & 7 & 2.9 & 233 & 97.1 & Iworo Ajido Badagry \\
Badagry heritage museum & 119 & 49.6 & 121 & 50.4 & Marina Badagry \\
\hline
\end{tabular}

Source: Field survey, 2018.

Purpose of Visit by tourists

The purposes of visit to the tourist sites by the respondents are presented in Table 3. The results show that the respondents visited the sites for educational purpose $(87.1 \%)$, research purpose $(84.2 \%)$, information purpose $(72.1 \%)$, recreation purpose $(62.1 \%)$ and sightseeing $(57.9 \%)$.

Table 3: Tourist Reasons for Visiting in the Study Area

\begin{tabular}{|c|c|c|c|c|}
\hline Reasons For Visiting Tourist Centre & Yes & & No & \\
\hline & Freq & $\%$ & Freq & $\%$ \\
\hline Recreation purposes & 149 & 62.1 & 91 & 37.9 \\
\hline Education purposes & 209 & 87.1 & 31 & 12.9 \\
\hline Holiday purposes & 7 & 2.9 & 233 & 97.1 \\
\hline Research purposes & 202 & 84.2 & 38 & 15.8 \\
\hline Information purposes & 173 & 72.1 & 67 & 27.9 \\
\hline Sightseeing purposes & 139 & 57.9 & 101 & 42.1 \\
\hline
\end{tabular}

Source: Field survey, 2018.

Patronage level of Tourist Sites

The results in Table 4 show the level of patronage of the tourist sites selected for the study. The study revealed that majority of the tourist sites were patronized frequently. Two tourist sites namely Sultan beach (79.2\%) and whispering palms $(55.8 \%)$ were being patronized always.

Table 4: Level of Patronage of Tourist Centers in the Study Area

\begin{tabular}{lllllllll}
\hline Tourist centre & \multicolumn{3}{c}{ Frequency of Patronage } \\
\cline { 2 - 10 } & Always & \multicolumn{3}{c}{ Frequently } & \multicolumn{2}{c}{ Seldomly } & \multicolumn{2}{c}{ Never } \\
& Freq & $\%$ & Freq & $\%$ & Freq & $\%$ & Freq & $\%$ \\
The first storey building in Nigeria & 82 & 34.2 & 156 & 65.0 & 2 & 0.8 & 0 & 0.0 \\
The slave relics of mobee palace & 75 & 31.3 & 143 & 59.6 & 22 & 9.2 & 0 & 0.0 \\
Q-brats Zoo & 77 & 32.1 & 143 & 59.6 & 20 & 8.3 & 0 & 0.0 \\
Nigeria French language village & 73 & 30.4 & 131 & 54.6 & 36 & 15.0 & 0 & 0.0 \\
Point of no return & 47 & 19.6 & 143 & 59.6 & 50 & 20.8 & 0 & 0.0 \\
Sultan Beach & 190 & 79.2 & 46 & 19.2 & 4 & 1.7 & 0 & 0.0 \\
Whispering palms & 134 & 55.8 & 54 & 22.5 & 52 & 21.7 & 0 & 0.0 \\
Badagry heritage museum & 113 & 47.1 & 70 & 29.2 & 57 & 23.8 & 0 & 0.0 \\
\hline
\end{tabular}

Source: Field survey, 2018.

\section{Level of Satisfaction of Tourists}

The result of the analysis in Table 5 show that majority $(99.6 \%)$ of the respondents were satisfied with the natural environment of the tourist centre. However, the results revealed that about $98.3 \%$ of the respondents were not satisfied with the infrastructural facilities within the tourist sites. Also, $57.1 \%$ of the respondents were not satisfied with the cleanliness of the tourist centre environment, suggested that lack of details cleaning of the tourist centres by cleaning personnel's. About $99.6 \%$ of the respondents were also dissatisfied with the road network of the 
tourist centre, which may in order easy of transportation within the tourist sites, as well as much more hours were spent on the road due to the poor road network.

Table 5: Level of Tourists' Satisfaction in the Study Area

\begin{tabular}{|c|c|c|c|c|c|c|c|c|}
\hline & \multicolumn{2}{|c|}{ Highly Satisfied } & \multicolumn{2}{|c|}{ Satisfied } & \multicolumn{2}{|c|}{ Indifferent } & \multicolumn{2}{|c|}{ Not satisfied } \\
\hline & Freq & $\%$ & Freq & $\%$ & Freq & $\%$ & Freq & $\%$ \\
\hline Accessibility & 0 & 0.0 & 238 & 99.2 & 0 & 0.0 & 2 & 0.8 \\
\hline $\begin{array}{l}\text { The attitude of the staff of the tourist } \\
\text { centre }\end{array}$ & 0 & 0.0 & 226 & 94.2 & 0 & 0.0 & 14 & 5.8 \\
\hline The recreational facilities & 0 & 0.0 & 188 & 78.3 & 0 & 0.0 & 52 & 21.7 \\
\hline $\begin{array}{l}\text { The natural environment of the tourist } \\
\text { centre }\end{array}$ & 0 & 0.0 & 239 & 99.6 & 0 & 0.0 & 1 & 0.4 \\
\hline Cultural and historical attractions & 0 & 0.0 & 233 & 97.1 & 0 & 0.0 & 7 & 2.9 \\
\hline Catering services and local cuisine & 0 & 0.0 & 205 & 85.4 & 0 & 0.0 & 35 & 14.6 \\
\hline Infrastructural facilities & 0 & 0.0 & 4 & 1.7 & 0 & 0.0 & 236 & 98.3 \\
\hline Service quality & 0 & 0.0 & 186 & 77.5 & 0 & 0.0 & 54 & 22.5 \\
\hline $\begin{array}{l}\text { Cleanliness of the tourist sites } \\
\text { environment }\end{array}$ & 0 & 0.0 & 103 & 42.9 & 0 & 0.0 & 137 & 57.1 \\
\hline $\begin{array}{l}\text { Safety and Security network of the } \\
\text { tourist centre }\end{array}$ & 0 & 0.0 & 230 & 95.8 & 0 & 0.0 & 10 & 4.2 \\
\hline The road network of the tourist centre & 0 & 0.0 & 1 & 0.4 & 0 & 0.0 & 239 & 99.6 \\
\hline The attitude of the local residents & 0 & 0.0 & 240 & 100.0 & 0 & 0.0 & 0 & 0.0 \\
\hline Entertainments & 0 & 0.0 & 240 & 100.0 & 0 & 0.0 & 0 & 0.0 \\
\hline Gate fee & 0 & 0.0 & 240 & 100.0 & 0 & 0.0 & 0 & 0.0 \\
\hline Achievement of visit purpose (s) & 0 & 0.0 & 240 & 100.0 & 0 & 0.0 & 0 & 0.0 \\
\hline
\end{tabular}

Source: Field survey, 2018.

\section{Challenges confronting tourist sites}

The results presented in Table 6 indicate that the tourist sites in the study area were being confronted with some challenges. Major among these challenges were inadequate funding of tourist centre by the government $(95.8 \%)$, under-developed tourism infrastructure (96.3\%) indicate that little resources is being provided for the development of tourist center was insufficient, thereby causing poor infrastructural development, limited understanding of tourism $(95.0 \%)$ and bad road to tourism destination which accounted for $98.3 \%$.

Table 6: Ascertain the Challenges Facing Tourist Centre In the Study Area

\begin{tabular}{lllll}
\hline Challenges & Agree & \multicolumn{3}{l}{ Disagree } \\
\hline & Freq & $\%$ & Freq & $\%$ \\
Local residents not hospitable & 0 & 0.0 & 240 & 100.0 \\
Language barriers & 0 & 0.0 & 240 & 100.0 \\
Insecurity & 0 & 0.0 & 240 & 100.0 \\
Inadequate funding by the government & 230 & 95.8 & 10 & 4.2 \\
Underdeveloped Tourism Infrastructure & 231 & 96.3 & 9 & 3.8 \\
Inadequate Marketing and publicity & 27 & 11.3 & 213 & 88.8 \\
Visa Restrictions & 0 & 0.0 & 240 & 100.0 \\
Limited understanding of tourism & 228 & 95.0 & 12 & 5.0 \\
High cost to tourism destinations & 56 & 23.3 & 184 & 76.7 \\
Bad road to tourism destinations & 236 & 98.3 & 4 & 1.7 \\
\hline
\end{tabular}

\section{Source: Field survey, 2018.}

\section{Hypothesis testing}

The results of the hypothesis test of relationship between selected socioeconomic characteristics of the tourist and their level of satisfaction are presented in Table 7. Results revealed that there was significant relationship $(\mathrm{p}<$ 0.05 ) between the socio-economic characteristics of the tourist and their level of satisfaction. This implies that age, sex, marital status, education, major occupation, working experience and household size of the respondents were associated with their level of satisfaction in the study area. 
Table7: Chi-square analysis of relationship between selected socio-economic characteristics of the tourist and their level of satisfaction

\begin{tabular}{llllll}
\hline S/N & Variables & Df & $\begin{array}{l}\boldsymbol{\chi}^{\mathbf{2}} \text { cal } \\
(\mathbf{0 . 0 5})\end{array}$ & $\begin{array}{l}\text { Significance } \\
(\mathbf{P} \leq \mathbf{0 . 0 5})\end{array}$ & Decision \\
\hline 1 & Age & 4 & $68.958^{\mathrm{a}}$ & 0.000 & Significant \\
2 & Sex & 1 & $14.017^{\mathrm{b}}$ & 0.000 & Significant \\
3 & Marital status & 2 & $185.925^{\mathrm{c}}$ & 0.000 & Significant \\
4 & Educational level & 2 & $19.600^{\mathrm{c}}$ & 0.000 & Significant \\
5 & Major occupation & 4 & $243.333^{\mathrm{a}}$ & 0.000 & Significant \\
6 & Working experience & 5 & $475.700^{\mathrm{e}}$ & 0.000 & Significant \\
7 & Household size & 3 & $193.367^{\mathrm{f}}$ & 0.000 & Significant \\
\hline
\end{tabular}

\section{Source: Field survey, 2018}

Furthermore, the results of the hypothesis test of relationship between the location of the tourist site and patronage of tourist site in the study area are presented in Table 8 . The results revealed that there was significant relationship $(p<0.05)$ between the location of the tourist site and patronage of tourist site in the study areas in the study area.

Table 8: Chi-square analysis of relationship between location of the tourist site and patronage of tourist site in the study areas.

\begin{tabular}{llllll}
\hline S/N & Variables & Df & $\begin{array}{l}\chi_{\text {cal }}^{2} \\
(\mathbf{0 . 0 5})\end{array}$ & $\begin{array}{l}\text { Significance } \\
(\mathbf{P} \leq \mathbf{0 . 0 5})\end{array}$ & Decision \\
\hline 1 & location vs patronage & 5 & $100.400^{\mathrm{b}}$ & 0.000 & Significant \\
\hline
\end{tabular}

Source: Field survey, 2018

\section{CONCLUSION AND RECOMMENDATIONS}

From the findings of the research, the patronage of tourist sites in the study area has to do with the location of the tourist site. The study discovered that Sultan beach and Whispering palms were the most patronized. The respondents were dissatisfied with the road network of the tourist centres meaning that much more hours were spent on the road due to the poor road network. The major challenges facing the tourist centres were inadequate funding of tourist centres by the government and under developed tourism infrastructures. The socioeconomic characteristics of the tourists had significant relationship on level of satisfaction of the tourists. Finally, there was significant relationship bwteen the location of the tourist centres and level patronage of tourist centres in Badagry Local Government Area of Lagos State. Arising from the study conclusion, the study recommended that:

i. Tourism development should not be left alone for the state government, the Local government should make effort to support the state government to create enabling environment to the tourist centre, as well as the tourist managers should complement the effort of government by improve high standard of environmental hygiene at the tourist site

ii. The infrastructural facilities at the tourist centres should be improved in order to further attract prospective tourists.

\section{References}

Ahmad, A.E.M.K. (2012). Attractiveness factors influencing shoppers' satisfaction, loyalty and word of mouth: An empirical investigation of Saudi Arabia shopping malls. International journal of business administration, 3(6), 101-124.

Bichaka, F., Christian.N.andBadassa, T.(2007). The Impact of Tourism on Economic Growth and Development in Africa.Department of Economics \& Finance Working Paper Series.Middle Tennessee State University.

Bogoro, P., Maimako, S.S.,\&Kurfi, A.K. (2013). Assessing the role of infrastructure on customer satisfaction with National Park in North East Nigeria.International journal of Scientific and Engineering Research, 4(10), 826843.

Chidoize, F.C., and Obudo, A.A. (2014) The Role of Cultural Heritage and Tourism in Nation Building: A study Lagos State Eyo Festival. Global Journal of Human-Social Science, 4(2). 23-24

Haller, A. (2012).Growth and Development through Tourism in Conditions of Liberalisation Theme and Concepts. Paper presented at the 14th International Conference 'Romanian Rural Tourism in Context of Sustainable Development; Present and Prospect' 25-26 May, 2012, VatraDornei, Romania.

Hodur, N. M., Leistristz, F. L., and Wolfe, K. L. (2005). Assessing the Economic Development Potential of Nature.Natural and Social Sciences, 15(Fall), 279-296.

Jennie, S. (2012). Tourism as a fast Growing Service Sector in India. Retrieved from www.tourism.enzinemark.com/tourism-as-fast-growing-service-sectorAccessed on 11/09/12

John, W.T. (2002). Making Parks Work; Strategies for Preserving Tropical Nature.Center for Tropical 
Conservation, Duke. Island Press, 2nd Edition.

Khaksari, A., Lee, T.J., \& Lee, C.K.. (2014) Religious Perceptions and Hegemony on Tourism Development: the case of the Islamic Republic of Iran. International Journal of Tourism Research, 16(1), 97-103.

Khosravi, S., \&Malek, A., \&Ekiz, E. (2014). Why Tourists are attached to boutique hotels: Case of Penang Island, Malaysia. Journal of Hospitality and Tourism, 12(1), 26-41.

Kumar, S., \& Malik, S. (2013).An empirical study of factors affecting hotel customer's satisfaction from front services \& facilities in Indian hospitality industry.A journal of Economics and Management, 2(3), 17-31.

Long, P. H. (2012). Tourism Impacts and Support for Tourism Development in Ha Long Bay, Vietnam; An Examination of Residents Perceptions. Asian Social Sciences, 8(8), 28-29.

Mosoma, D., (2014). Effect of internal customer care on employee satisfaction in Tanzania's small and medium hotel industry enterprises. International Journal of Business and Management Review, 2(3), 17-31.

Newsome, D., Moore, S. A., \& Dowling, R. K. (2002).Natural Area Tourism: Ecology, Impacts and Management. NY: Channel View Publication.

Raymond, Y. C. (2001). Estimating the Impact of Economic Factors on Tourism ; Evidence from HongKong. Tourism Economics, 7(3), 277-293.

World Trade Organisation (WTO) (2016 ). Tourism and poverty alleviation: Recommendation for action Spain. Madrid: World Trade Organisation.

WTTC (2018).World Travel and Tourism Council, 2014 \& 2015. The Authority on World Travel and Tourism: Travel and Tourism Economic Impact on Nigeria. 